\title{
A laser Doppler velocimetry study of the effect of hypoglycaemia on retinal blood flow in the minipig
}

\author{
G. Caldwell, E. G. Davies, P.M. Sullivan, A. H.C.Morris and E. M. Kohner \\ Department of Medicine, Royal Postgraduate Medical School, London, UK
}

Summary. The effect of acute hypoglycaemia (plasma glucose $<2.2 \mathrm{mmol} / \mathrm{l}$ ) on retinal venous blood flow in the minipig has been determined using bidirectional laser Doppler velocimetry and red free retinal photography. In six pigs the mean flow in a retinal vein increased from 19.3 ( $\pm 2.8 \mathrm{SEM}) \mu 1 / \mathrm{min}$ to $29.7( \pm 7.5) \mu 1 /$ min during hypogly- caemia $(p<0.05)$ with a return to $18.6( \pm 3.6) \mu 1 / \mathrm{min}$ when euglycaemia was restored. Retinal blood flow is affected by hypoglycaemia or its haemodynamic consequences.

Key words: Retinal blood flow, hypoglycaemia, laser Doppler velocimetry.
Alterations in retinal blood flow may be involved in the pathogenesis of diabetic retinopathy [1-5]. Changes in vessel diameter, maximum flow velocity, and reactivity to oxygen have been reported, with reversion towards normal following photocoagulation [5-7]. These changes may, at least in part, be consequent upon fluctuations in blood glucose [8-10]. There have been no previous reports of retinal blood flow in hypoglycaemia and we report our findings in the Gottingen minipig.

\section{Materials and methods}

\section{Animals}

Minipigs of the Gottingen breed, supplied from the Royal Vetinary College, London, UK, were caged in groups of three with free access to food and water. The pigs, weighing between 6 and $22 \mathrm{~kg}$ were fasted from the evening before the experiment.

\section{Anaesthesia and surgery}

Anaesthesia was induced with Halothane (May and Baker, Dagenham, Essex, UK) and maintained with nitrous oxide in oxygen and boluses of i.v. metomidate (Jannsen, Wantage, Oxon., UK), to maintain deep anaesthesia. When fully anaesthetised the minipigs were paralysed with tubocurarine (Duncan Flockhart, Greenford, Middx., UK). An arterial line for blood pressure and blood gas monitoring was sited in the aorta via a popliteal or femoral cut down, and a central venous line for drug administration and collection of blood samples was similarly inserted. Blood gases were checked every $90 \mathrm{~min}$ and the $\mathrm{PaO}_{2}$ maintained between 110 and $130 \mathrm{~mm} \mathrm{Hg}$ and the $\mathrm{PaCO}_{2}$ between 30 and $40 \mathrm{~mm} \mathrm{Hg}$. The minipig was placed prone with the head supported and the left cornea exposed by suturing back the eyelids. Sutures through the extra-ocular muscles allowed for positioning and stabilisation of the eye. The pupil was dilated with cyclopentolate $1 \%$ (Smith and Nephew, Hull, Yorks., UK) and the exposed cornea was covered with a contact lens and kept clean and moist with sodium hyaluronate (Healonid, Pharmacia, Uppsala, Sweden). Intra-ocular pressure was recorded in the right eye using a Perkins applanation tonometer.

\section{Blood flow measurements}

The laser Doppler velocimeter (LDV) readings were performed using a bidirectional laser Doppler velocimeter manufactured by Oculix Ltd. (Philadelphia, Pa., USA) the details of which have been described elsewhere $[11,12]$. The velocimeter is a modified Topcon fundus camera. A Helium-Neon laser beam (wavelength 632.8 nanometers) is focused on the vessel of interest and the frequency of the waveform is modified by the velocity of the erythrocytes. Two fibreoptic tubes in the retinal image plane of the camera collect scattered light from the retina bidirectionally to allow absolute velocity determination. The scattered light is processed by a signal analyser and the data is then acquired and stored by a Masscomp super minicomputer. Data is analysed using a computer algorithm to determine spectral cutoff in selected spectral pairs. The difference between maximal frequency shifts of the spectral pairs allows determination of blood flow velocity. The maximum centre line velocity $\left(\mathrm{V}_{\mathrm{max}}\right)$ was determined from the mean of the analysis of at least 12 spectral pairs with sharp, well defined cutoff points. Data from veins is more reproducible than those from arteries mainly because the pulsatile nature of arterial flow makes calculation of mean arterial velocity more difficult [5]. In addition, the signal ana- 


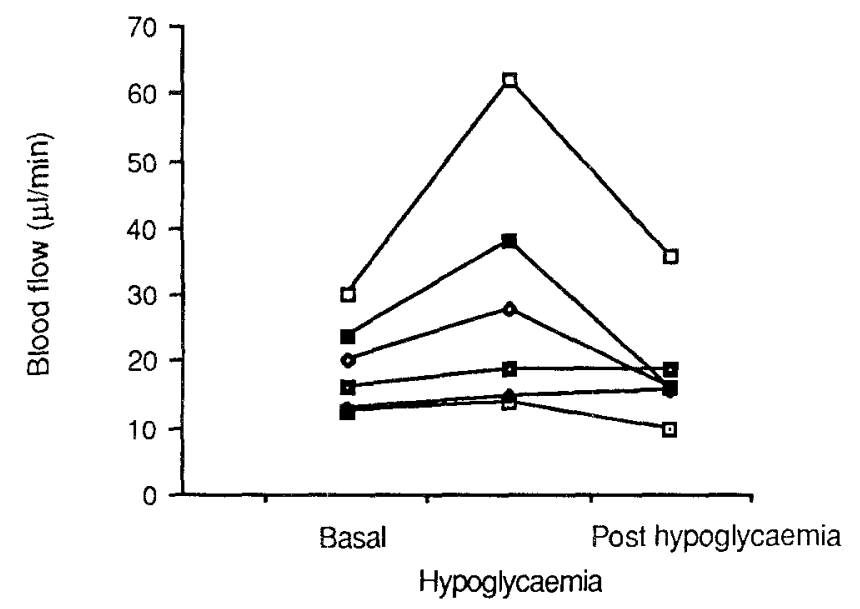

Fig. 1. Retinal blood flow in six minipigs before, during and after insulin induced hypoglycaemia

lyser available is not fast enough for analysis of rapid changes in the artery. The LDV measurements were taken from a vein within two optic disc diameters of the disc margin and at least six vessel diameters away from any bifurcations to ensure laminar flow. Red free retinal photographs of the vessel were taken at each glucose level to determine the vessel diameter at the site of the recordings. The vessel diameter was determined by a computer digitisation system [13]. Flow was calculated from the formula

$\mathrm{Q}=\left(\pi \cdot \mathrm{D}^{2} / 4\right) \times\left(\mathrm{V}_{\mathrm{MAX}} / 2\right)$

where $Q$ is the flow, and $D$ is the vessel diameter. The factor of 2 in the formula arises from the assumption of Poiseuille flow [14].

\section{Perfusion pressure}

The ocular perfusion pressure was calculated from the mean blood pressure, with a correction for the fall in blood pressure from the aorta to the ophthalmic artery [15], less the intraocular pressure, thus

$P P=[0.67 \times(D p+0.33 \times\{S p-D p\})]-I O P$

where $\mathrm{PP}$ is the perfusion pressure at the eye, $\mathrm{Dp}$ the diastolic and $\mathrm{Sp}$ the systolic pressure from the aortic pressure trace, and IOP the intra-ocular pressure.

IOP was measured in the fellow eye, as the eye under study had a contact lens applied to prevent drying.

\section{Hypoglycaemia}

Hypoglycaemia was induced by the i.v. administration of $0.15 \mathrm{U} / \mathrm{kg}$ of porcine Velosulin (Nordisk, Epsom, Surrey, UK). Plasma glucose was measured every 5-10 min using a Glucose Analyser 2 (Beckman Instruments, Fullerton, Calif., USA) and velocimetry recordings taken when the plasma glucose was $<2.2 \mathrm{mmol} / \mathrm{l}$ on two occasions $5 \mathrm{~min}$ apart. After the recordings were taken hydrocortisone $(1 \mathrm{mg} / \mathrm{kg})$ was given i.v. to aid recovery from hypoglycaemia, because metomidate is known to inhibit cortisol synthesis [16], and we observed slow recovery when hydrocortisone was not given. The final recordings were taken when the plasma glucose was $>5.0 \mathrm{mmol} / \mathrm{l}$ on two occasions $5 \mathrm{~min}$ apart. This occurred $30-60 \mathrm{~min}$ after discontinuation of insulin.

\section{Statistical analysis}

The Wilcoxon signed rank test for paired data was used to compare data when the pigs were euglycaemic with that when hypoglycaemic. Significance was taken as $p<0.05$.

\section{Results}

The changes in blood glucose, vessel diameter, and flow are summarised in Table 1 . The mean flow when euglycaemic was $19.3( \pm 2.8 \mathrm{SEM}) \mu \mathrm{l}$ per min and increased by $44( \pm 18) \%$ to $29.7( \pm 7.5) \mu \mathrm{l}$ per $\min (p<0.05)$ when the minipigs were hypoglycaemic, and returned to $18.6( \pm 3.6) \mu \mathrm{l}$ per min when euglycaemia was restored (Fig.1). The change in flow was mainly attributable to an increase in $\mathrm{V}_{\operatorname{MAX}}$ from $1.38( \pm 0.24)$ to $1.86( \pm 0.40) \mathrm{cm} \cdot \mathrm{s}^{-1}$ (NS), there being little change in vessel diameter. During hypoglycaemia there was an increase in systolic pressure from $135( \pm 10)$ to $145( \pm 8) \mathrm{mm} \mathrm{Hg}(\mathrm{NS})$, in pulse rate from $122( \pm 20)$ to $135( \pm 19)$ (NS) and a decrease in diastolic pressure from $96( \pm 5)$ to $83( \pm 5)(\mathrm{NS})$ and in perfusion pressure from $60.2( \pm 5.3) \mathrm{mm} \mathrm{Hg}$ to $57.6( \pm 5.3) \mathrm{mm} \mathrm{Hg}$ (NS).

\section{Discussion}

We have demonstrated a $44 \%$ increase in retinal blood flow during hypoglycaemia in the anaesthetised minipig. The anaesthetic agents employed in this study may have interfered with adaptive mechanisms active in conscious animals and the results must be interpreted with caution. The blood flow fell as euglycaemia was restored, but the change did not reach statistical significance. This may have been because hormonal and autonomic counter-

Table 1. Data in six minipigs when euglycaemic, hypoglycaemic and after recovery from hypoglycaemia. Values are shown as mean \pm SEM

\begin{tabular}{|c|c|c|c|}
\hline & Before & $\begin{array}{l}\text { During } \\
\text { hypogly- } \\
\text { caemia }\end{array}$ & After \\
\hline Plasma glucose $(\mathrm{mmol} / \mathrm{l})$ & $6.1 \pm 0.4$ & $1.6 \pm 0.1^{\mathrm{a}}$ & $6.3 \pm 0.6$ \\
\hline $\begin{array}{l}\text { Systolic aortic pressure } \\
(\mathrm{mm} \mathrm{Hg})\end{array}$ & $135 \pm 10$ & $145 \pm 8$ & $138 \pm 9$ \\
\hline $\begin{array}{l}\text { Diastolic aortic pressure } \\
(\mathrm{mm} \mathrm{Hg})\end{array}$ & $96 \pm 5$ & $83 \pm 5$ & $86 \pm 9$ \\
\hline Pulse rate (beats/min) & $122 \pm 20$ & $135 \pm 19$ & $130 \pm 16$ \\
\hline $\begin{array}{l}\text { Intraocular pressure } \\
(\mathrm{mm} \mathrm{Hg})\end{array}$ & $14.8 \pm 1.3$ & $14.8 \pm 0.9$ & $16.4 \pm 0.6$ \\
\hline $\begin{array}{l}\text { Ocular perfusion pressure } \\
(\mathrm{mm} \mathrm{Hg})\end{array}$ & $60.2 \pm 5.3$ & $57.6 \pm 5.3$ & $60.2 \pm 6.1$ \\
\hline Vessel diameter (microns) & $302 \pm 10$ & $308 \pm 15$ & $291 \pm 11$ \\
\hline$V_{\operatorname{MAX}}\left(\mathrm{cm} \cdot \mathrm{s}^{-1}\right)$ & $1.38 \pm 0.24$ & $1.86 \pm 0.40$ & $1.24 \pm 0.10$ \\
\hline Flow $(\mu \mathrm{l} / \mathrm{min})$ & $19.3 \pm 2.8$ & $29.7 \pm 7.5^{\mathrm{a}}$ & $18.6 \pm 3.6$ \\
\hline
\end{tabular}

a values statistically different $(p<0.05)$ from those when initially euglycaemic 
regulatory mechanisms were still active, or because of the limited power of a study with a small number of animals.

Autoregulation in the retinal circulation maintains a steady blood flow despite moderate changes in perfusion pressure, although autoregulation fails with large rises or falls in perfusion pressure $[15,17-20]$. We are unaware of any previous studies of retinal blood flow in hypoglycaemia, and indeed these would be difficult to perform in man because during hypoglycaemia there is spontaneous slow movement of the eye. The retina is embryologically and physiologically part of the brain and increased cerebral blood flow has been observed during hypoglycaemia in man $[21,22]$. The mechanism leading to increased flow in hypoglycaemia is open to debate. In hypoglycaemia there is a rise in heart rate, ejection fraction, stroke volume and cardiac output [23, 24], and a fall in intraocular pressure [25], consequent upon stimulation of the sympathetic nervous system. Autoregulation would be expected to maintain the same blood flow despite the increased cardiac output. The retinal vessels have no direct sympathetic or parasympathetic nerve supply [26], but the vasculature does have receptors for a variety of vasoactive agents including angiotensin and adrenergic agonists [2729], and the increased retinal blood flow could be consequent upon changes in the systemic concentration of such agents during hypoglycaemia. If the sympathetic and parasympathetic transmitters are involved in any way, it would be expected that the responses would be reduced in patients with autonomic neuropathy as was seen in cerebral blood flow in one case [22], and requires investigation in a larger study. Another possibility is that the increased retinal blood flow reflects failure of autoregulation in hypoglycaemia. We believe, however, that it is more likely that the increased flow in hypoglycaemia is an adaptive mechanism to stress to maintain function of essential tissues. Similarly, when retinal function is stressed by a fall in perfusion pressure, induced either by manipulating intraocular pressure or mean arterial pressure, retinal blood flow is maintained [17-19].

Recently a deterioration in retinopathy has been reported when diabetic control was improved using intensified insulin treatment. These patients have an increased incidence of clinical and especially subclinical hypoglycaemia [31-33]. Retinal blood flow during hypoglycaemia has not been studied in these patients, although when euglycaemic it is higher than in patients whose retinopathy did not deteriorate [34]. Failure of autoregulation of cerebral blood flow in the face of altered perfusion pressure has been described in Type 1 (insulin-dependent) diabetic patients with retinopathy and nephropathy [35], and it may be that responses to hypoglycaemia would also be impaired. If the increase in retinal blood flow, which we have observed during hypoglycaemia in the minipig, failed to occur in diabetic patients damage to the retina could ensue.

The increase in retinal blood flow in hypoglycaemia would appear to be protective to preserve retinal function in the face of limited nutrient supply. In diabetic patients this protective mechanism could fail leading to retinal damage. Similar adaptive mechanisms apply in the cere- bral circulation, and laser Doppler studies of retinal blood flow may prove to be a simple method of studying the control of cerebral blood flow.

Acknowledgements. This work was supported by the Juvenile Diabetes Foundation, Nordisk Industries, and the British Diabetic Association.

\section{References}

1. Kohner EM, Hamilton AM, Saunders SJ, Sutcliffe BA, Bulpitt CJ (1975) The retinal blood flow in diabetes. Diabetologia 11: 27-33

2. Blair NP, Feke GT, Morales-Stoppello J, Riva CE, Goger DG, Collas GD, McMeel JW (1982) Prolongation of the retinal mean circulation time in diabetes. Arch Ophthalmol 100: 764-768

3. Yoshida A, Feke GT, Morales-Stoppello J, Collas GD, Goger DG, McMeel JW (1983) Retinal blood flow alterations during progression of diabetic retinopathy. Arch Ophthalmol 101: 225227

4. Fallon TJ, Chowiencyzk P, Kohner EM (1986) Measurement of retinal blood flow in diabetes by the blue light entoptic phenomenon. Br J Ophthalmol 70: 43-46

5. Grunwald JE, Riva CE, Sinclair SH, Brucker AJ, Petrig BL (1986) Laser Doppler velocimetry study of retinal circulation in diabetes mellitus. Arch Ophthalmol 104: 991-996

6. Grunwald JE, Riva CE, Brucker AJ, Sinclair SH, Petrig BL (1984) Altered retinal vascular response to $100 \%$ oxygen breathing in diabetes mellitus. Ophthalmology 91: 1447-1452

7. Grunwald JE, Riva CE, Martin DB, Ouint AR, Epstein PA (1987) Effect of an insulin-induced decrease in blood glucose on the human diabetic retinal circulation. Ophthalmology 94: 1614 1620

8. Ernest JT, Goldstick TK, Engerman RL (1983) Hyperglycaemia impairs retinal oxygen autoregulation in normal and diabetic dogs. Invest Ophthalmol Vis Sci 24: 985-989

9. Read JS, Ernest JT, Goldstick TK, Raichman M, Petersen AC (1980) Hyperglycaemia and the retinal microcirculation in man. Invest Ophthalmol Vis Sci 19 [Suppl]: 168

10. Atherton A, Hill DW, Keen H, Young S, Edwards EJ (1980) The effect of acute hyperglycaemia on the retinal circulation of the normal cat. Diabetologia 18: 233-237

11. Riva CE, Grunwald JE, Sinclair SH, O’Keefe K (1981) Fundus camera based retinal laser Doppler velocimetry. Appl Optics 20: $117-120$

12. Riva CE, Grunwald JE, Sinclair SH, Petrig BL (1985) Blood velocity and volumetric flow rate in human retinal vessels. Invest Ophthalmol Vis Sci 26: 1124-1132

13. Sleightholm MA, Arnold JV, Aldington SJ, Kohner EM (1984) Computerised digitisation of fundus photographs. Clin Physiol Meas 5:295-301

14. Feke GT, Tagawa H, Deupree DM, Goger DG, Sebag J, Weiter JJ (1989) Blood flow in the normal human retina. Invest Ophthalmol Vis Sci 30: $58-65$

15. Robinson F, Riva CE, Grunwald JE, Petrig BL, Sinclair SH (1986) Retinal blood flow autoregulation in response to an acute increase in blood pressure. Invest Ophthalmol Vis Sci 27: 722 726

16. Neumann R, Worek F, Gutsch W, Pham L, Blumel G, Zimmermann $G$ (1986) Reconstitution of cortisol prevents circulatory failure in septic pigs anaesthetised with metomidate. Abstracts of the International Symposium of Anaesthesia for Cardiac Patients, Society for Cardiovascular Anaesthetists. Munich, Germany, $\mathrm{p} 230$

17. Ffytche TJ, Bulpitt CJ, Kohner EM, Archer D, Dollery CT (1974) Effect of changes in intra-ocular pressure on the retinal microcirculation. Br J Ophthalmol 58: 514-522 
18. Riva CE, Sinclair SH, Grunwald JE (1981) Autoregulation of retinal circulation in response to decrease of perfusion pressure. Invest Ophthalmol Vis Sci 21: 34-38

19. Grunwald JE, Riva CE, Kozart DM (1988) Retinal circulation during a spontaneous rise of intraocular pressure. Br J Ophthalmol 72: 754-758

20. Grunwald JE, Sinclair SH, Riva CE (1982) Autoregulation of retinal circulation in response to decrease of intraocular pressure below normal. Invest Ophthalmol Vis Sci 23: 124-126

21. Porta PD, Maiolo AT, Negri VU, Rossella E (1964) Cerebral blood flow and metabolism in therapeutic insulin coma. Metabolism 13: 131-140

22. Neil HAW, Gale EAM, Hamilton SJC, Lopez-Espinoza I, Kaura R, McCarthy ST (1987) Cerebral blood flow in Type 1 (insulindependent) diabetic patients and control subjects. Diabetologia 30: 305-309

23. Hilsted J, Bonde-Peterson F, Norgaard M-B, Greniman M, Christensen NJ, Parring H-H, Suzuki M (1984) Haemodynamic changes in insulin-induced hypoglycaemia in normal man. Diabetologia $26: 328-332$

24. Fisher BM, Gillen G, Dargie HJ, Inglis G, Frier BM (1987) The effects of insulin-induced hypoglycaemia on cardiovascular function in normal man: studies using radionuclide ventriculography. Diabetologia 30: $841-845$

25. Frier BM, Hepburn DA, Fisher BM, Barrie T (1987) Fall in intraocular pressure during acute hypoglycaemia in patients with insulin dependent diabetes. Br Med J 295: 610-611

26. Laties AM (1967) Central retinal artery innervation. Absence of adrenergic innervation to the intraocular branches. Arch Ophthalmol 77: 405-409

27. Dollery CT, Hill DW, Hodge JV (1963) The response of normal retinal blood vessels to angiotensin and noradrenaline. J Physiol 165: 500-507

28. Grunwald JE (1986) Effect of topical timolol on the human retinal circulation. Invest Ophthalmol Vis Sci 27: 1713-1719
29. Hoste AM, Boels PJ, Brutaert DL, De Laey JJ (1989) Effect of alpha-1 and beta agonists on contraction of bovine retinal resistance arteries in vitro. Invest Ophthalmol Vis Sci 30: 44-50

30. Lauritzen T, Frost-Larsen K, Deckert T (1983) The Steno Study Group. Effect of one year of near-normal blood glucose levels on retinopathy in insulin dependent diabetes. Lancet I: 200-204

31. The Kroc Collaborative Study Group (1984) Blood glucose control and the evolution of diabetic retinopathy and albuminuria. $N$ Engl J Med 311: 365-372

32. Dahl-Jorgensen K, Brinchmann-Hansen O, Hanssen KF, Sandvik $\mathrm{L}$, Aagenaes $\mathrm{O}$ (1985) Rapid tightening of blood glucose control leads to transient deterioration of retinopathy in insulin dependent diabetes mellitus; the Oslo Study. Br Med J 290:811-815

33. Brinchmann-Hansen O, Dahl-Jorgensen K, Hanssen KF, Sandvik $L(1985)$ The Oslo Study. Effects of intensified insulin treatment on various lesions of diabetic retinopathy. Am J Ophthalmol 100: 644-653

34. Grunwald JE, Brucker AJ, Braunstein SN, Schwartz L, Petrig BL, Riva CE (1989) Effect of improvement in diabetic control on retinal blood flow. Invest Ophthalmol Vis Sci 30 [Suppl]: 434

35. Kastrup J, Rorsgaard S, Parving HH, Lassen VA (1986) Impaired autoregulation of cerebral blood flow in long-term type 1 (insulin dependent) diabetic patients with nephropathy and retinopathy. Clin Physiol 6: 549-559

Received: 7 August 1989

and in revised form: 18 December 1989

\section{Prof. E. M. Kohner}

Department of Medicine

Royal Postgraduate Medical School

Du Cane Road

London W12 ONN

UK 